Volodymyr D. Pohrebennyk, Full professor, D. S., Professor at the Department of Ecological Safety and Nature Protection Activity of V. Chornovil Institute for Sustainable Development

ORCID ID 0000-0002-1491-2356 e-mail:vpohreb@gmail.com

Khrystyna R. Hamkalo, student

Lviv Polytechnic National University, Lviv, Ukraine

\title{
THE STATE OF DRINKING WATER QUALITY ON THE EXAMPLE OF SLUPSK CITY (POLAND) AND ZHYDACHIV DISTRICT (UKRAINE)
} Abstract. The problem of drinking water quality is extremely relevant. According to
the World Health Organization (WHO) every year about $25 \%$ of the world's
population is at risk consumption of low-quality drinking water, and more than $80 \%$
of all human diseases are directly related to the use of low-quality water. The aim
of the work is to compare the quality of drinking water on the example of the city of
Slupsk (Poland) and Zhydachiv district of the Lviv region (Ukraine). The following
methods of water quality research are used in this work: visual, nephelometric,
potentiometric, conductometric, titration, spectrophotometric and membrane
filtration.

A comparison of drinking water quality in Slupsk (Poland) and Zhydachiv district (Lviv region, Ukraine) has been performed. The requirements for drinking water quality in Poland and Ukraine are the same.

In Slupsk (Poland), residents consume water of centralized water supply, which is taken from the horizons with a depth of 50-180 m. Then water enters in the water treatment station, where it is cleaned by aeration and filtration. No chemicals, reagents and disinfectants are added to the water. The block diagram of the technological process at the water preparation station in Slupsk, the scheme of processes for reducing the concentration of iron and manganese, and the results of experimental research on drinking water are presented. Water in Slupsk meets almost all the requirements for the quality of drinking water, except for the compounds of iron and manganese. Therefore, during the purification of water, the removal of these compounds occurs, after which the drinking water meets all the requirements set. Water quality monitoring in Slupsk is carried out continuously at the different stages of production and distribution. It is carried out by two independent laboratories. There are the accredited laboratory of "Water Supply Slupsk" and the laboratory of the regional sanitary and epidemiological station in Slupsk.

Residents of Zhydachiv district use water for both centralized and decentralized water supply. There is a crisis situation with drinking water supply in this area. It has been found that all water samples do not meet the requirements for bacterial parameters and have high iron content. In some samples there is a steady increase in permanganate oxidation and ammonia nitrogen, as well as an excess of chloride, fluorine, dry residue and nitrates. Indicators of $\mathrm{pH}$ of water samples taken from wells of different depths and from the crane meet the established norms. Water from the wells has almost by 2 times higher level of specific electrical conductivity water from the tap. The purification of drinking water, which is carried out at the disinfection stations at water intakes of City Municipal Enterprise "Zhydachivvodokanal" and Open Joint Stock Company “Kokhavynska Paper Factory”, is insufficient.

Keywords: drinking water quality; technological processes at the water preparation station; water purification; experimental research

(C) V.D. Pohrebennyk, K.R. Hamkalo, 2018

ISSN: 2411-4049. Екологічна безпека та природокористування, № 4 (28), 2018 


\title{
В.Д. Погребенник, Х.Р. Гамкало
}

Національний університет «Львівська політехніка», м. Львів, Україна

\section{СТАН ЯКОСТІ ПИТНОЇ ВОДИ НА ПРИКЛАДІ М. СЛУПСЬК (ПОЛЬЩА) ТА ЖИДАЧІВСЬКОГО РАЙОНУ (УКРАЇНА)}

\begin{abstract}
Анотація. Виконано порівняння якості питної води у м. Слупськ (Польща) та Жидачівському районі (Львівщина, Украӥна). Подано блок-схему технологічного прочесу на станиії підготовки води в Слупську, схеми процесів зменшення концентрачії заліза та марганџю, результати експериментальних досліджень питної води.
\end{abstract}

Ключові слова: якість питної води; технологічні процеси на станції підготовки води; очищення води; експериментальні дослідження

\section{Вступ}

Проблема якості питної води була і продовжує залишатись надзвичайно актуальною [1]. У результаті глобального техногенного впливу на природу, вода, як їі вагома життєдайна складова, зазнає значних змін, що негативно впливають на діяльність та здоров'я людей [2]. Це призводить до виникнення різноманітних захворювань, які можуть мати летальні наслідки [1]. За даними Всесвітньої Організації Охорони Здоров’я (ВОО3), щороку у світі близько 25\% населення піддається ризику споживання неякісної питної води, а більше як $80 \%$ усіх захворювань людини безпосередньо пов'язано із вживанням неякісної води, до складу якої входять речовини, що можуть викликати мутагенні та канцерогенні ефекти. Тому надзвичайно важливо здійснювати контроль за якістю питної води.

В основу водного законодавства європейських країн - членів СС покладено “Директиву про питну воду” ЄС 80/778/ЄС. У Директиві нормують 66 показників якості питної води. Однак у 1998 р. Радою СС замість неї прийнято нову Директиву 98/83/СС “Про якість питної води, призначеної для споживання людиною”. У цих нормативних документах у питній воді нормують такі групи показників: загальні фізико-хімічні; органолептичні; мікробіологічні і паразитологічні; радіологічні; гранично допустимі концентрації вмісту основних неорганічних та органічних речовин у питній воді.

Перш ніж потрапити у мережу водогонів, вода повинна пройти очищення, щоб відповідати вимогам до якості питної води, встановленим Розпорядженням Міністра охорони здоров'я Польщі від 29 березня 2007 р. “Про якість води, призначеної для споживання людиною” [2].

В Україні склад і властивості питної води повинні відповідати вимогам ДСанПіН 2.2.4-171-10 "Гігієнічні вимоги до води питної, призначеної для споживання людиною” [1].

Метою роботи $є$ порівняння стану якості питної води на прикладі міста Слупськ (Польща) і Жидачівського району Львівської області (Україна). 


\section{Аналіз останніх досліджень і публікацій}

Неякісна вода, забруднена системами водопостачання, і відсутність належної гігієни є основними причинами захворювань як в країнах, що розвиваються, так і розвинених країнах. Встановлено, що можна було б зменшити спалахи інфекцій до $10 \%$ тільки поліпшенням якості води та гігієни. Традиційні методи, засновані на моніторингу якості води з джерел, не є достатніми для забезпечення якісної питної води. Інформація про поганий стан води приходить занадто пізно і не може запобігти використанню води у разі їі забруднення, а також є не достатньою для ідентифікації джерела забруднення. ВООЗ рекомендує розроблення і реалізацію плану забезпечення безпеки води в системах колективного водопостачання.

В Україні майже 40 відсотків водогонів застаріли або й взагалі в аварійному стані. Нині міське водопостачання забезпечується в Україні за рахунок підземних вод лише на 25\%. Для більшості країн Європи використання підземних вод досягає 90\%, що забезпечує задоволення потреб населення високоякісною питною водою.

Питанням якості питної води присвячено публікації [3-6]. Значного прогресу у поліпшенні якості води досягли країни ЄС. Тому Україні варто перейняти їх досвід. Вельми актуальним є порівняння стану якості води в Україні та у найближчого сусіда - Польщі.

\section{Методи досліджень}

У роботі використано такі методи дослідження якості води: візуальний, нефелометричний, потенціометричний, кондуктометричний, титрування, спектрофотометричний та мембранної фільтрації.

\section{Виклад основних результатів}

Повіт Слупський розташовано безпосередньо на головному резервуарі підземних вод (№ 17 “Битув”) і на двох місцевих водоймах підземних вод (“Викопна долина Маховино" і “Слупськ”). Джерелом питного водопостачання у Слупську є два незалежні водозабори: “Вестерплатте” та “Глобино". Ці води відбирають з четвертинних відкладень водоносного горизонту з глибиною від 50 до 180 м нижче рівня землі [7].

Характерною особливістю грунтових вод у Слупську є підвищений вміст заліза, марганцю. Ці елементи видаляють очисні споруди за рахунок аерації та фільтрації [1]. У Польщі для питної води нижня межа твердості питної води становить 60 мг/л для карбонату кальцію і 30 мг/л - для магнію. Вода, яка постачається жителям м. Слупськ, має середню жорсткість (середнє значення твердості становить 208 мг/л $\mathrm{CaCO}_{3}$ - за допустимого значення 500 мг/л $\mathrm{CaCO}_{3}$ ). Питна вода, яка поставляється через “Водоканал Слупськ”, містить близько 70,2 мг/л кальцію і 6,4 мг/л магнію, що є задовільним.

Характерні для підземних вод надлишки домішок заліза і марганцю, а також $\mathrm{CO}_{2}$ i $\mathrm{H}_{2} \mathrm{~S}$ викликали необхідність будівництва станції очищення води в Слупську, в якій використовують безреагентну технологію, засновану на природних процесах. Вода, яка постачається через станцію очищення, $€$ хімічно і мікробіологічно стабільною, що задовольняє всім сучасним вимогам 
i рекомендаціям - як вітчизняним, так і Свропейського Союзу. Додатковою перевагою води $є$ той факт, що добрий стан водопровідної мережі дає змогу уникнути хлорування води [8]. Блок-схему технологічного процесу на станції підготовки води в м. Слупськ показано на рис. 1.

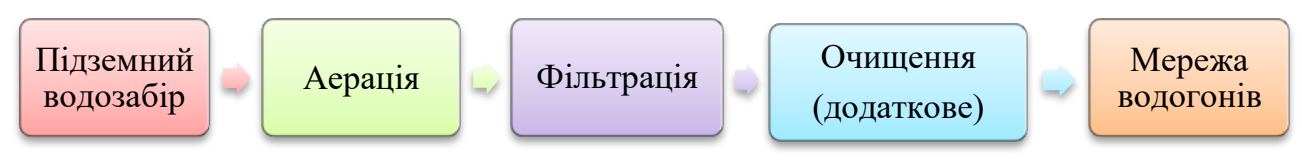

Рис. 1 - Блок-схема технологічного процесу на станції підготовки води в м. Слупськ

Процес видалення 3 води сполук заліза засновано на окисненні всіх розчинних форм двовалентного Fe (II) до нерозчинного у воді тривалентного $\mathrm{Fe}$ (III), а потім видаленні з води отриманих сполук Fe (III). Видалення марганцю протікає аналогічно, за винятком того, що сполука двовалентного Mn (II) окиснюється з утворенням чотиривалентного Mn (IV). Сполуки заліза i марганцю, які випали в осад, потім видаляють 3 води за допомогою фільтрації. Вода надходить до станції системою трубопроводів 3 двох водозаборів, змішується та потрапляє в зал аераторів, де піддається процесу аерації. Аерація води здійснюється через чотири каскадні аератори, завданням яких є насичення киснем сирої води і видалення газів, розчинених у воді, тобто сірководню і вуглекислого газу. Вода подається у верхню частину аератора, а потім стікає вниз решітками в нижню частину аератора (рис. 2).

Після того як вода, збагачена повітрям, надходить в реакційну камеру, функція якої полягає в подовженні контакту води 3 повітрям, відбувається часткове осадження розчинених твердих речовин (переважно заліза), звідки далі завдяки силі тяжіння вода надходить у фільтрувальні камери (рис. 3).

Необхідну кількість кисню на окиснювання сполук заліза $\mathrm{Fe}$, марганцю $\mathrm{Mn}$ і амонійного іона $\mathrm{NH}_{4}$ розраховано за формулою:

$$
Z=F e^{*} A+M n * B+N_{4} *\left[\text { M2 } O_{2} / л\right],
$$

де: $A$ - кількість кисню на окислювання сполук заліза $\mathrm{Fe} ; 0,14$ мг $\mathrm{O}_{2} / 1$ мг Fe/л; $B$ - кількість кисню на окислювання марганцю Mn; 0,29 мг $\mathrm{O}_{2} / 1$ мг Mn/л; $C$ - кількість кисню на окислювання амонійного іона $\mathrm{NH}_{4} ; 4,57$ мг $\mathrm{O}_{2} / 1$ мг $\mathrm{NH}_{4} / л$; $\mathrm{Fe}, \mathrm{Mn}, \mathrm{NH}_{4}$ - вміст цих параметрів у сирій змішаній воді [мг/л].

За формулою (1), а також на підставі результатів досліджень розраховано середню потребу кисню у воді, яка склала 0,37 мг $\mathrm{O}_{2} /$ л. Відповідно до технологічних вказівок, вміст кисню у воді після фільтрації має бути не менше ніж 2,5-3 мг $\mathrm{O}_{2} /$ л. 

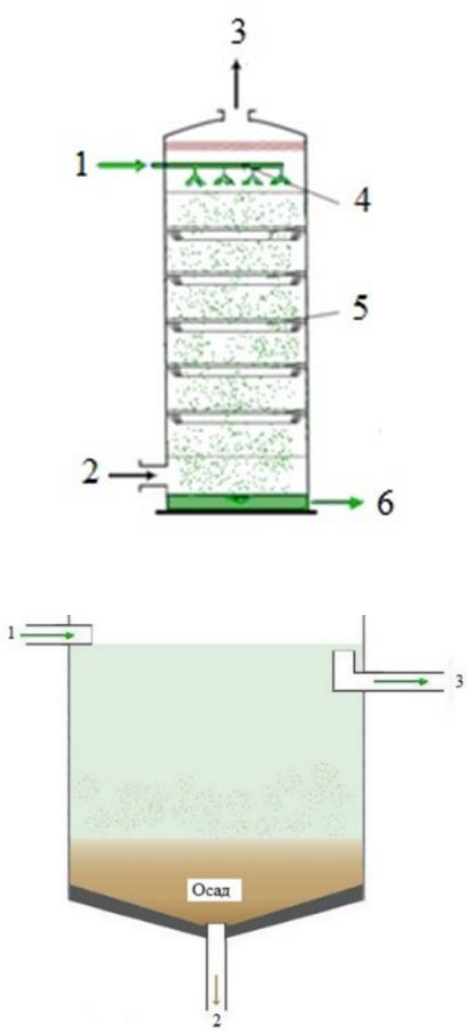

Рис. 2 - Процес аерації: 1 - подача води; 2 - подача повітря; 3 - видалення 3 води діоксиду вуглецю i сірководню; 4 розпилення води; 5 - решітка; 6 - відведення води, збагаченої повітрям, у реакційну камеру
Рис. 3 - Реакційна камера: 1 - подача води, збагаченої повітрям, у реакційну камеру; 2 вихід осаду; 3 - вивід води, збагаченої повітрям, у фільтрувальні камери

Вміст кисню у воді, після іiі збагачення, в середньому становить 12,6 мг $\mathrm{O}_{2} /$ л. Вода досягла рівня максимального насичення киснем за температури $10^{\circ} \mathrm{C}(>80 \%$, умову виконано).

Середній вміст кисню в очищеній воді становить близько 10 мг $\mathrm{O}_{2} /$ л, отже, умову виконано [8]. Процес збагачення води киснем зображено на рис. 4.

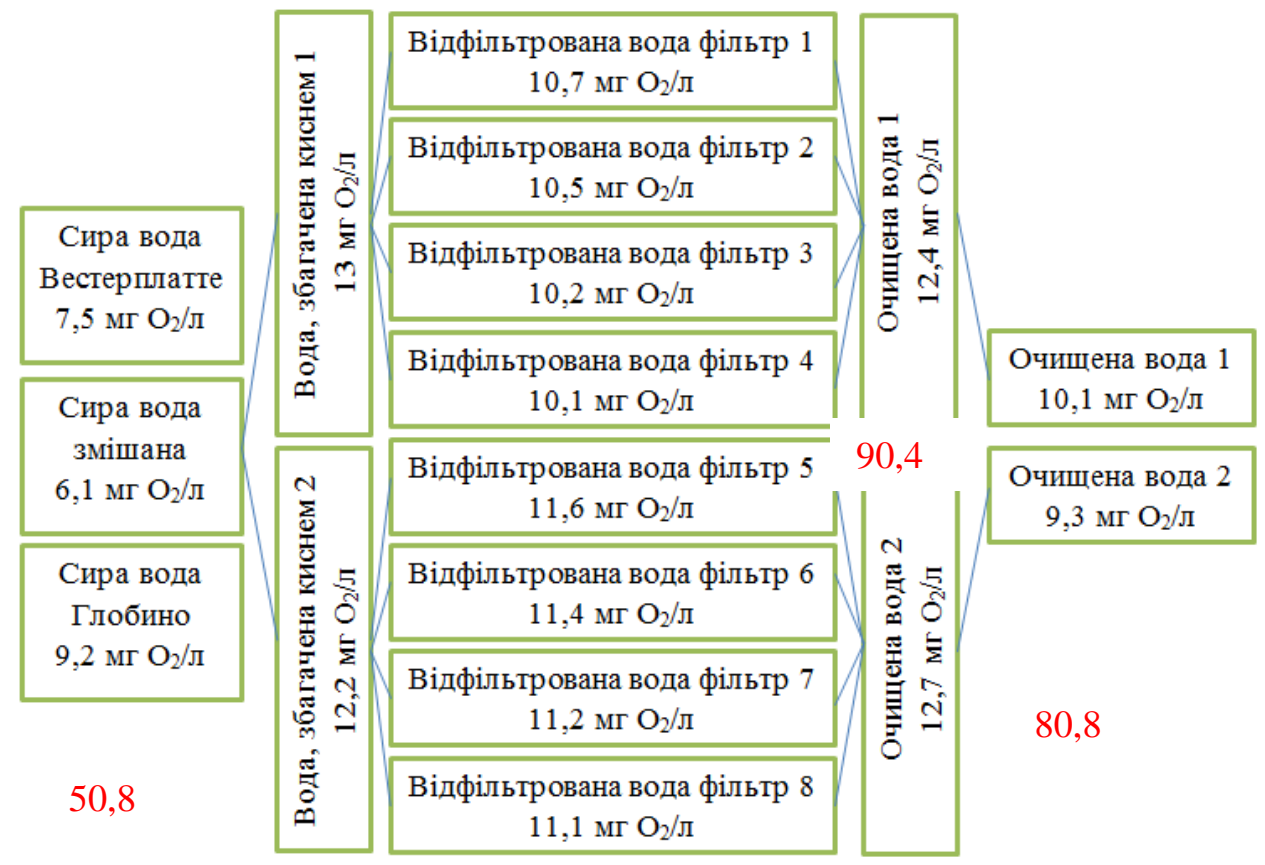

Рис. 4 - Схема процесу збагачення води киснем 
Фільтрувальні камери - це відкриті резервуари, заповнені фільтрувальним шаром, який містить кварцовий пісок розміром із зерно. Сполуки заліза i марганцю, які осідають 3 води, утримують у фільтрувальному шарі. Воду, що проходить через кварцовий пісок, збирають у зливному фільтрі, а потім направляють в резервуари очищеної води, звідки за допомогою насоса вона надходить до водопровідної мережі (рис. 5) [2].

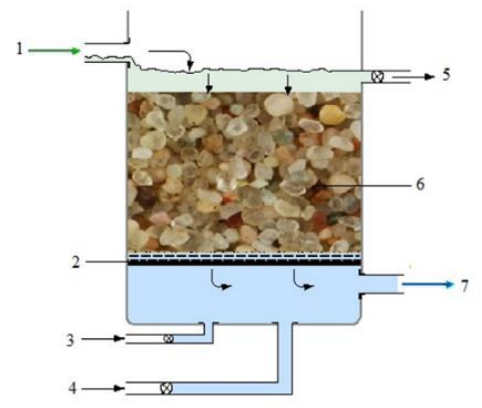

Рис. 5 - Фільтрувальна камера: 1 - подача води, збагаченої повітрям; 2 - фільтрувальний шар; 3 - патрубок для промивання фільтрувального шару повітрям; 4 - патрубок для промивання фільтрувального шару водою; 5 - вивід забруднювачів після регенерації фільтрувального шару; 6 - кварцовий пісок; 7 - відведення очищеної води

Процес фільтрації полягає у зменшенні концентрації заліза Fe (рис. 6) та марганцю Mn (рис. 7). Нормативна концентрація заліза Fe становить 0,002 мг Fe/л, марганцю Mn - 0,05 мг Mn/л [8]. Результати моніторингу якості води, який виконують безперервно на різних етапах виробництва і розподілу дві незалежні лабораторії - акредитована лабораторія фірми "Водоканал Слупськ” і лабораторія районної санітарно-епідеміологічної станції у Слупську, показують, що вода, доступна для жителів міста, є не тільки смачною, але й корисною [9].

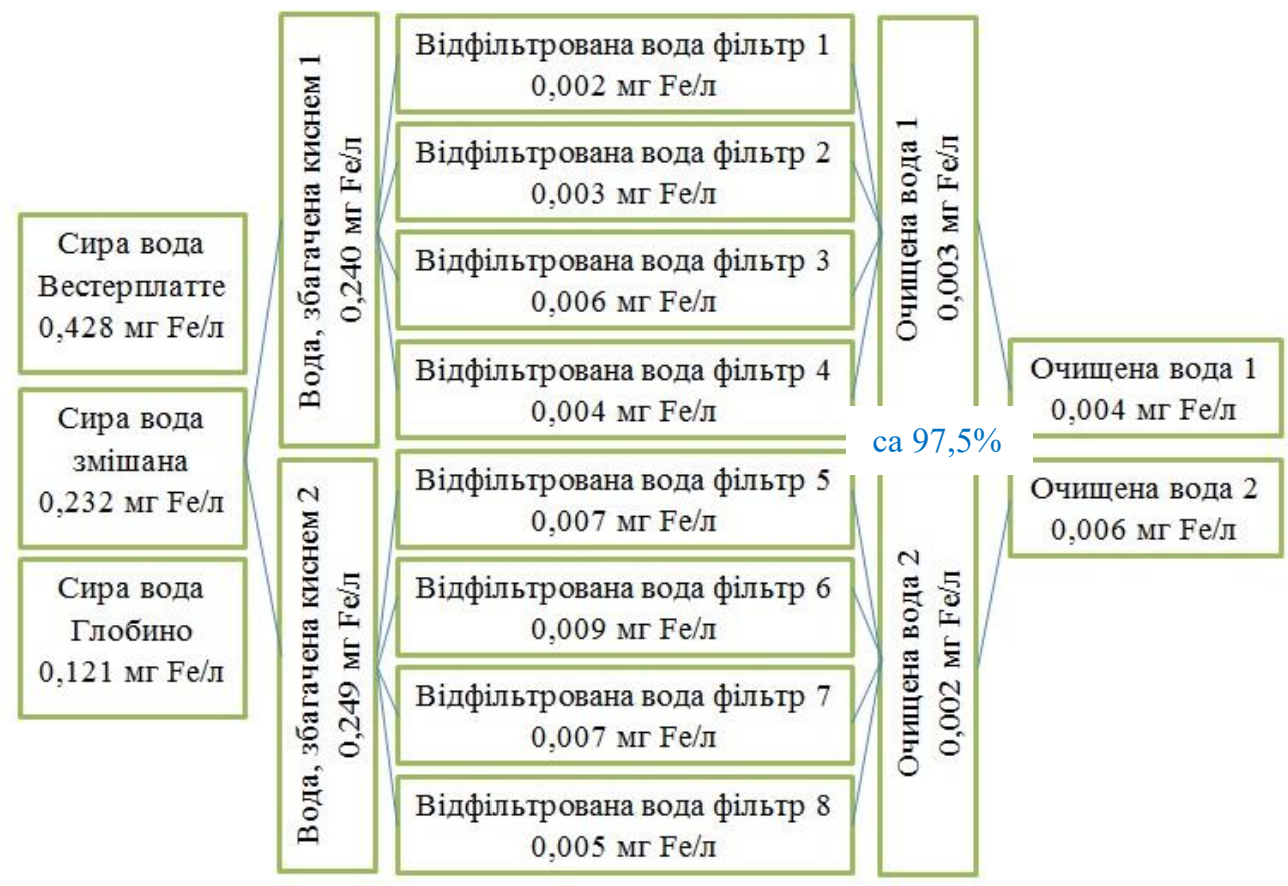

Рис. 6 - Схема процесу зменшення концентрації заліза $\mathrm{Fe}$ 


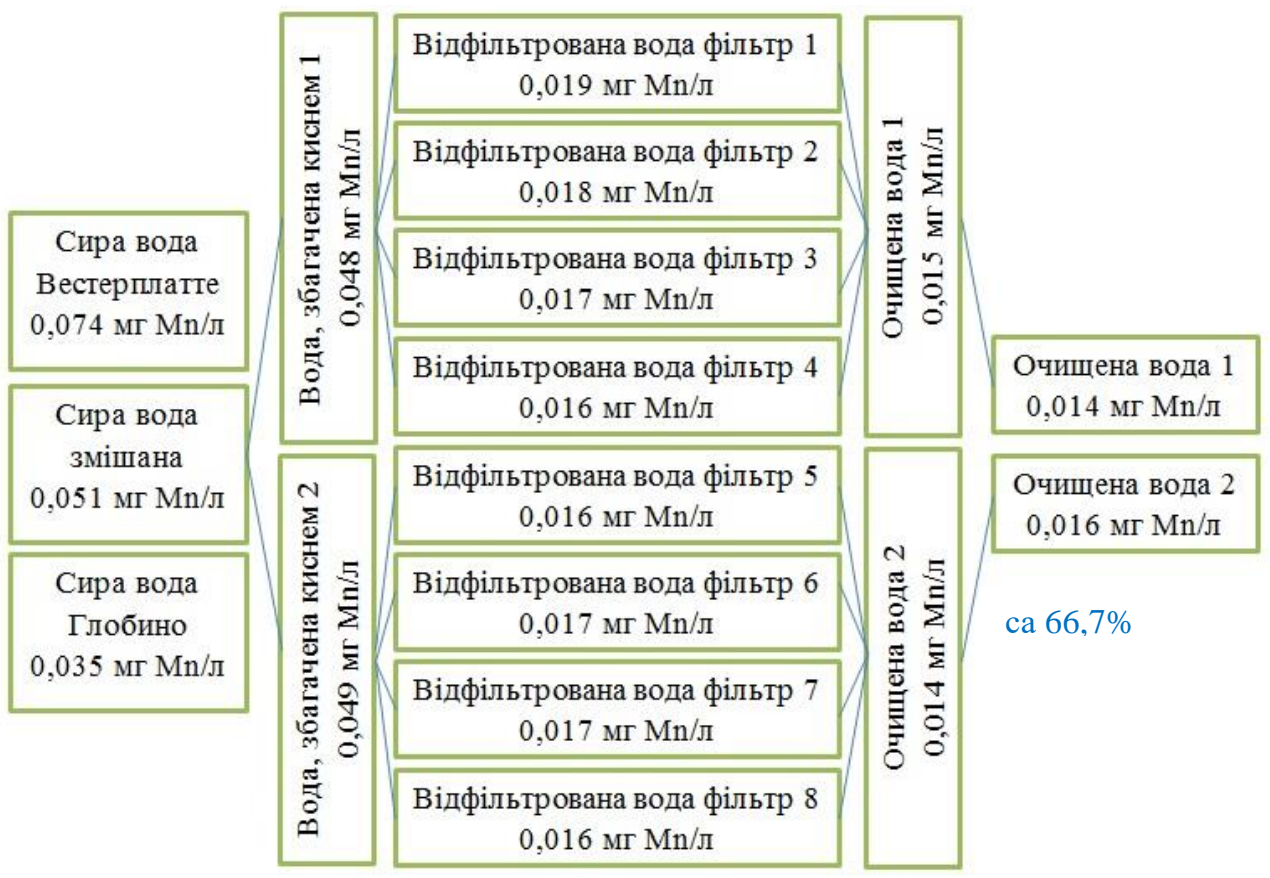

Рис. 7 - Схема процесу зменшення концентрації марганцю Mn

Результати досліджень якості питної води в Слупську подано у таблиці.

Таблиця - Результати досліджень показників питної води в Слупську

\begin{tabular}{|c|c|c|}
\hline Показники & Середнє значення & Вимоги \\
\hline Запах & прийнятний & $\begin{array}{c}\text { прийнятний i } \\
\text { без аномальних змін }\end{array}$ \\
\hline Колір, мг/л Pt & прийнятний & $\begin{array}{c}\text { прийнятний i } \\
\text { без аномальних змін }\end{array}$ \\
\hline Каламутність, NTU & 0,4 & $\leq 1$ \\
\hline $\mathrm{pH}$ & 7,8 & $6,5-9,5$ \\
\hline Фториди, мг/л & $<0,1$ & $\leq 1,5$ \\
\hline Питома електропровідність, мкСм/см & 448 & $\leq 2500$ \\
\hline Нітрити, мг/л & $<0,005$ & $\leq 0,5$ \\
\hline Нітрати, мг/л & 10,6 & $\leq 50,0$ \\
\hline Йони амонію, мг/л & $<0,1$ & $\leq 0,50$ \\
\hline Загальна твердість, мг/л & 208 & $60-500$ \\
\hline Залізо, мг/л & $<0,03$ & $\leq 0,2$ \\
\hline Хлориди, мг/л & 16,0 & $\leq 250$ \\
\hline Перманганатна окислюваність, мг/л & $<0,5$ & $\leq 5,0$ \\
\hline Марганець, мг/л & 0,02 & $\leq 0,05$ \\
\hline Сульфати, мг/л & 47 & $\leq 250$ \\
\hline $\begin{array}{c}\text { Бактерії групи кишкової палички, } \\
\text { к-сть/100 мл } \\
\end{array}$ & 0 & 0 \\
\hline Ентерококи, к-сть/100 мл & 0 & 0 \\
\hline $\begin{array}{c}\text { Загальне число бактерій за температури } \\
22{ }^{\circ} \mathrm{C} \text { після } 72 \text { год., к-сть/1 мл }\end{array}$ & 10 & $\begin{array}{c}\text { немає аномальних } \\
\text { змін } \\
\end{array}$ \\
\hline
\end{tabular}


У Жидачівському районі Львівської області джерелом питного водопостачання $\epsilon$ підземні води. Водозабір прісних підземних вод Жидачівського району має 4 свердловини загальною потужністю 3,5 тис. м ${ }^{3}$ на добу. У результаті повені 23-27.07.2008 р. одна свердловина вийшла повністю із ладу і вже не підлягає відновленню. Три свердловини, які підпорядковані КП “Журавножитлосервіс", знаходяться у задовільному стані.

На території району розміщено 14 водозаборів централізованого водопостачання населення, із них 5 комунальних, 6 відомчих та 3 сільських [10]. Якість питної води, що використовується населенням району, нині погіршилася. Питома вага незадовільних проб питної води на вміст хімічних речовин та відсоток невідповідності проб води на бактеріологічні показники в окремих адміністративних одиницях району (населених пунктах) $\epsilon$ незадовільними. Більша частина задіяних водопроводів не відповідає санітарним нормам. У водозаборі в с. Жирова виявлено високий вміст заліза [10]. У м. Жидачів вода у свердловинах за якісними характеристиками потребує доочищення з огляду на високий вміст заліза - у межах 15-19 мг/дм³.

У деяких пробах виявлено зростання значень перманганатної окислюваності та азоту амонійного, які характеризують органічне забруднення, перевищення за вмістом хлоридів, фтору, заліза, сухого залишку та нітратів. Загальна твердість води - більше 8 мг-екв/л, що перевищує допустимі норми [11]. Перманганатна окислюваність знаходиться в межах 5-7 мг $\mathrm{O}_{2} /$ л за норми 5 мг $\mathrm{O}_{2} /$ л, а азот амонійний $\left(\mathrm{NH}^{+4}\right)-1,5-2$ мг/л, норма 2 мг/л. За даними ДП “Західукргеологія” та санепідемстанції питна вода, яку подають із свердловин, що обслуговує КП “Журавножитлосервіс”, є в доброму стані. У водопровідній воді 3 Дев'ятниківської ЗОШ I-III ступеня i Дев'ятниківського водозабору виявлено бактерії групи кишкової палички - 23, за норми - 3, що може призводити до спалахів гострих кишкових захворювань. У м. Жидачів, м. Ходорів, смт. Гніздичів 3 джерел централізованого водопостачання воду подають 3 перевищенням за вмістом хлоридів, фтору, заліза, сухого залишку. Рівень нітратів у питній воді значно перевищує нормативний показник у населених пунктах Ходорів, Гніздичів, Кам'яне, Піддністряни, Садки, Дев'ятники, Іванівці, Заріччі та ряду інших [5].

За даними ДСанПіН 2.2.4-171-10 водневий показник $(\mathrm{pH})$ повинен бути в межах 6,5-8,5 [11]. Результати досліджень води, взятої 3 криниць різної глибини та з крану, показали, що показники усіх проб знаходяться в межах норми. Рівень рН у воді становить 6,9-7,5 (рис. 8).

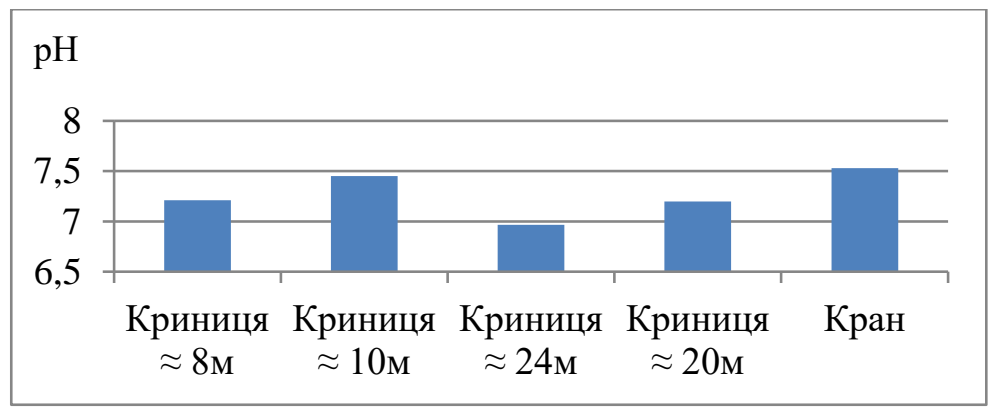

Рис. 8 - Значення рН у пробах води з криниць та крану 
Найменший показник $\mathrm{pH}$ у пробі води, взятої з криниці глибиною 24 м 6,9 , а найбільший у криниці глибиною 10 м - 7,4, у воді з крану рН становить

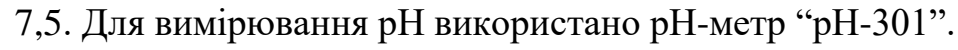

Питома електропровідність води залежить від ступеня іiі мінералізації, 3 підвищенням мінералізації вона збільшується. Мінеральну частину води становлять йони $\mathrm{Na}^{+}, \mathrm{K}^{+}, \mathrm{Ca}^{2+}, \mathrm{Cl}^{-}, \mathrm{SO}_{4}{ }^{2-}, \mathrm{HCO}_{3}{ }^{-}$[12].

Результати вимірювань питомої електропровідності за приладу DIST-3 зображено на рис. 9.

На діаграмах (рис. 10-13) зображено порівняння середніх показників якості води у м. Слупськ і Жидачівському р-ні відповідно.

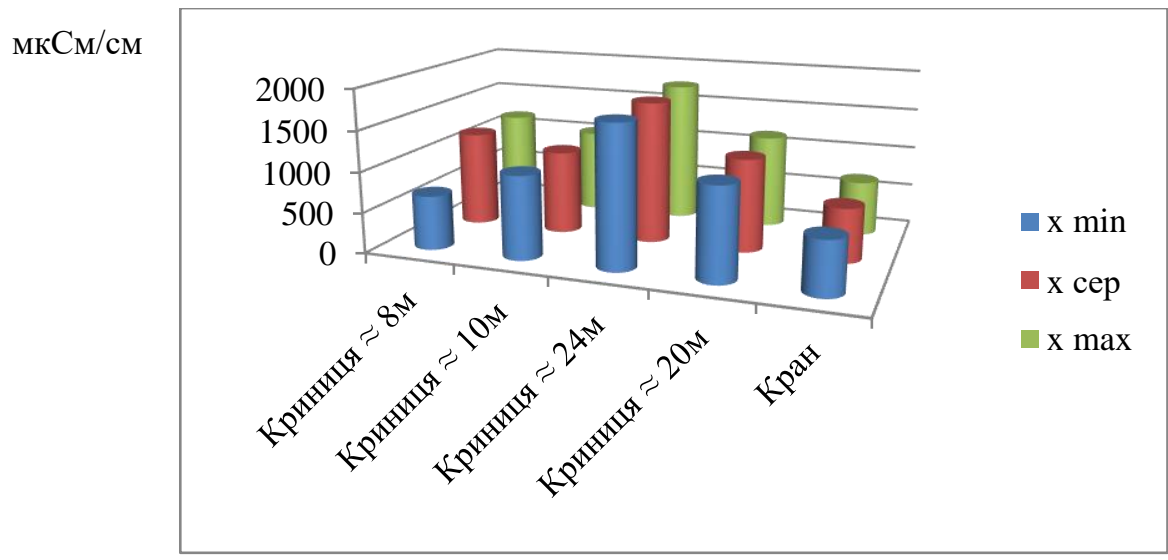

Рис. 9 - Значення питомої електропровідності питної води

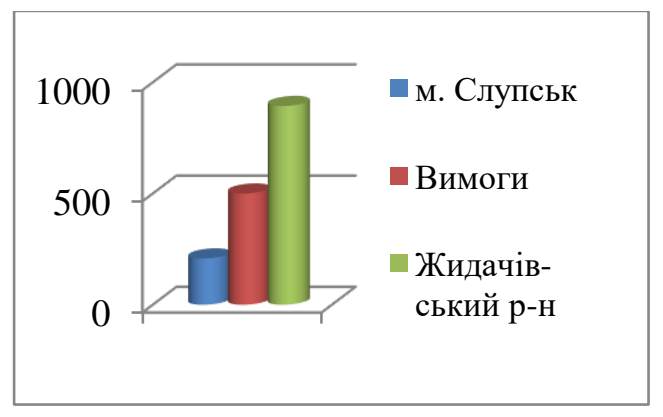

Рис. 10 - Значення загальної твердості, мг/л

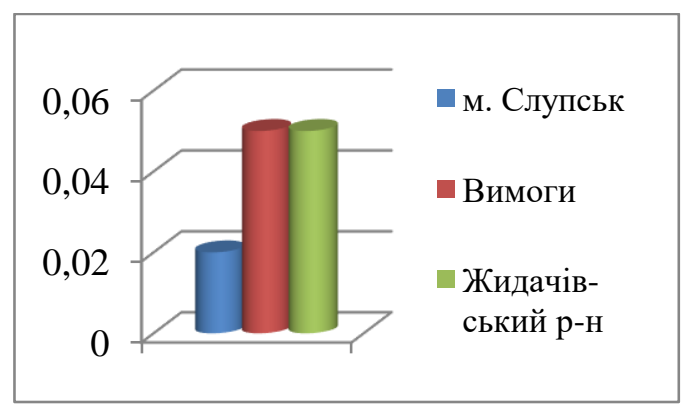

Рис. 12 - Вміст марганцю, мг/л

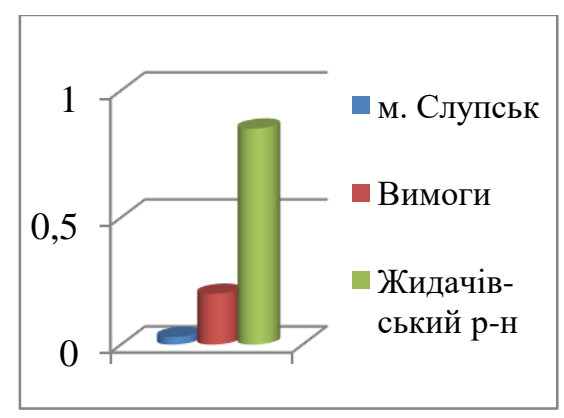

Рис. 11 - Вміст заліза, мг/л

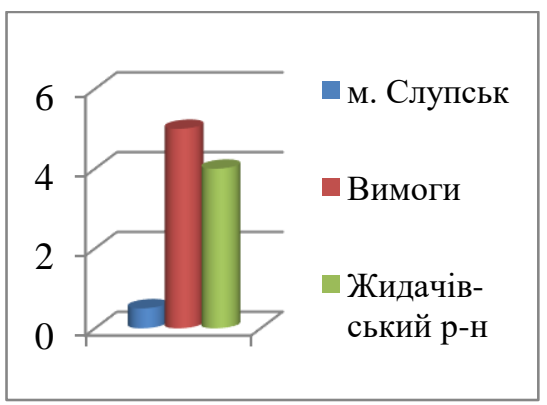

Рис. 13 - Значення перманганатної окиснюваності, мг/л 
Вимоги до якості питної води у Польщі і Україні однакові. Відрізняються лише вимоги до $\mathrm{pH}$ : у Польщі - 6,5-9,5, в Україні - 6,5-8,5. Нормам не відповідають лише два показники у воді Жидачівського р-ну: вміст заліза у воді перевищує встановлені норми у 4 рази (вимоги - 0,2 мг/л, фактичний вміст 0,85 мг/л) і показник загальної твердості на 393,6 мг/л (вимоги - 60-500 мг/л, фактичний вміст - 893,6 мг/л). У м. Слупськ усі показники води відповідають встановленим вимогам.

\section{Висновки}

1. У м. Слупськ (Польща) жителі споживають воду централізованого водопостачання, яку відбирають з горизонтів глибиною 50-180 м. Потім вода надходить на станцію підготовки води, де відбувається iі очищення за допомогою аерації і фільтрації. До води не додають жодних хімічних речовин, реактивів та дезінфікувальних засобів. Вода у м. Слупськ відповідає майже всім вимогам до якості питної води, за винятком сполук заліза і марганцю. Тому під час очищення води відбувається видалення цих сполук, після чого питна вода повністю відповідає усім встановленим вимогам. Моніторинг якості води у Слупську виконують безперервно на різних етапах виробництва i розподілу. Його здійснюють дві незалежні лабораторії - акредитована лабораторія фірми “Водоканал Слупськ” і лабораторія районної санітарноепідеміологічної станції Слупська.

2. Жителі Жидачівського р-ну споживають воду як централізованого, так і децентралізованого водопостачання. У районі склалася кризова ситуація 3 питним водопостачанням. Виявлено, що усі проби води не відповідають вимогам за бактеріальними показниками, а також мають високий вміст заліза. У деяких пробах спостерігається стійке зростання перманганатної окиснюваності і азоту амонійного, а також перевищення вмісту хлоридів, фтору, сухого залишку та нітратів. Показники рН проб води, взятих з криниць різної глибини та з крану, відповідають встановленим нормам. Вода 3 криниць має майже у 2 рази більшу питому електропровідність, ніж вода 3 крану. Очищення питної води, яке проводиться на станціях знезараження на водозаборах МКП “Жидачівводоканал” та ВАТ “Кохавинська ПФ”, є недостатнім.

\section{СПИСОК ЛІТЕРАТУРИ}

1. Гамкало Х.Р. Стан якості питної води у Польщі та Україні на прикладі м. Слупськ і Жидачівського району / Х.Р. Гамкало, В.Д. Погребенник // Матеріали Міжн. наук.практ. конф. "Прикладні науково-технічні дослідження” (5-7 квітня 2017 р., Україна, Івано-Франківськ). - Івано-Франківськ: Симфонія форте, 2017. - С. 9.

2. Гамкало Х. Р. Методи очищення питної води в м. Слупськ (Польща) / Х.Р. Гамкало, В.Д. Погребенник // Збірник наукових праць “VI-й Всеукраїнський з'їзд екологів 3 міжнародною участю” (20-22 вересня 2017 р., Україна, Вінниця. - 2017. - С. 54.

3. ISO 7888:1985 Water quality - Determination of electrical conductivity. Edition: 1, Stage: 90.93 , TC $147 / \mathrm{SC} 2 .-8 \mathrm{p}$.

4. Water Security: Monograph. - Mykolaiv: PMBSNU, Ukraine - Bristol: UWE, United Kingdom edited by Olena Mitryasova, Chad Staddon. $-2016 .-308$ p.

5. Батмангхелідж Ф. Вода для здоров'я. Пер. з англійської. - Мн. Попурі, 2006. - 544 с. 
6. Філонова К.В. Проблема якості питної води в Україні / К.В. Філонова, С.В. Міськевич // Збірник наукових праць “І-й Всеукраїнський з'їзд екологів" (4-7 жовтня 2006, Україна, Вінниця) - С. 243.

7. Radzka E. System zarządzania jakością wody pitnej w Polsce / E. Radzka, J. Jankowska // Zeszyty naukowe Uniwersytetu przyrodniczo-humanistycznego w siedlcach, Seria: Administracja i Zarządzanie (34) 2015. - Siedlcy, 2015. (S.22)

8. http://www.wodociagi.slupsk.pl/dla-klientow-2/plan-bezpieczenstwa-wody/teren-zlewni/

9. http://www.wodociagi.slupsk.pl/dla-klientow-2/jakosc-wody-w-slupsku/kwestia-tzwkamienia/

10. Коваль С. Програма "Питна вода" на території Жидачівського району до 2020 року / С. Коваль, Р. Баліцький. - Жидачів, 2010. - 68 с.

11. Державні санітарні норми та правила "Гігієнічні вимоги до води питної, призначеної для споживання людиною” (ДСанПіН 2.2.4-171-10), 2010.

12. Походило Є. Контроль якості води за електричними параметрами / С. Походило, О. Гонсор // Метрологія та вимірювальна техніка, № 68, 2008. - С. 237-242.

Стаття надійшла до редакції 29.10.2018

\section{REFERENCES (TRANSLATED AND TRANSLITERATED)}

1. Xamkalo, K. R., \& Pogrebennyk, V. D. (2017). The state of drinking water quality in Poland and Ukraine on the example of Slupsk city and Zhydachiv district. In Intern. Scientific and Practical Conference "Applied scientific and technical research" (p. 9). IvanoFrankivs'k: Symfonija forte( in Ukrainian).

2. Xamkalo, K. R., \& Pogrebennyk, V. D. (2017). Metody ochyshhennja pytnoi' vody v m. Slups'k (Pol'shha). In Zbirnyk Naukovyh Prac' “VI-j Vseukrai'ns'kyj Z'i'zd Ekologiv Z Mizhnarodnoju Uchastju” (p. 54). Vinnycja (in Ukrainian).

3. ISO 7888:1985 Water quality - Determination of electrical conductivity. Edition: 1, Stage: 90.93 , TC 147/SC 2. -8 p. (in English).

4. Mitryasova, O., \& Staddon, C. (Eds.). (2016). Water Security. Mykolaiv: PMBSNU, Ukraine - Bristol: UWE, United Kingdom (in English).

5. Batmanghelidj, F. (2006). Water For Health. Sankt-Peterburg: Popurry (in English).

6. Filonova, K. V., \& Mis'kevych, S. V. (2006). Problema jakosti pytnoi' vody v Ukrai'ni. In Zbirnyk Naukovyh Prac' “I-j Vseukrai'ns'kyj z'i'zd ekologiv” (p. 243). Vinnycja (in Ukrainian).

7. Radzka, E., \& Jankowska, J. (2015). System zarządzania jakością wody pitnej w Polsce. Zeszyty Naukowe Uniwersytetu Przyrodniczo-humanistycznego W Siedlcach, Seria: administracja i zarzadzanie, (34), (p. 22). Siedlcy (in Polish).

8. (n.d.). Retrieved from http://www.wodociagi.slupsk.pl/dla-klientow-2/planbezpieczenstwa-wody/teren-zlewni/ (in Polish).

9. (n.d.). Kwestia tzw. kamienia. Retrieved from http://www.wodociagi.slupsk.pl/dlaklientow-2/jakosc-wody-w-slupsku/kwestia-tzw-kamienia/ (in Polish).

10. Koval', S., \& Balic'kyj, R. (2010). Program "Drinking water" in the territory of Zhydachiv district until 2020. Zhydachiv (in Ukrainian).

11. DSanPiN 2.2.4-171-10 "Gigijenichni vymogy do vody pytnoi', pryznachenoi' dlja spozhyvannja ljudynoju”. (2010). Kyiv: Oficijnyj visnyk Ukrai'ny (in Ukrainian).

12. Pohodylo, J. \& Gonsor, O., (2008). Kontrol' jakosti vody za elektrychnymy parametramy. Metrologija Ta Vymirjuval'na Tehnika, (68), 237-242 (in Ukrainian).

Text of the article was accepted by Editorial Team 29.10.2018 


\section{Погребенник Володимир Дмитрович}

професор, доктор технічних наук, професор кафедри екологічної безпеки та природоохоронної діяльності Інституту сталого розвитку ім. В. Чорновола Національного університету «Львівська політехніка»

Адреса робоча: 79057 Україна, м. Львів, вул. Генерала Чупринки, 130

Тел.: 0985782530 e-mail: vpohreb@gmail.com

ORCID ID 0000-0002-1491-2356

\section{Гамкало Христина Романівна}

студент 5-го курсу Інституту сталого розвитку ім. В. Чорновола Національного університету «Львівська політехніка»

Адреса робоча: 79057 Україна, м. Львів, вул. Генерала Чупринки, 130

Тел.: 097321 4976; e-mail: khrystynka128@ gmail.com 